\title{
A novel CD74-ROS1 gene fusion in a patient with inflammatory breast cancer: a case report
}

\author{
Huiyu Hu ${ }^{1,2}$, Nianhua Ding ${ }^{3}$, Haiyan Zhou ${ }^{4}$, Shouman Wang ${ }^{1,2}$, Lili Tang ${ }^{1,2^{*}}$ and Zhi Xiao ${ }^{1,2^{*}}$ (D)
}

\begin{abstract}
Background: CD74-ROS1 fusion genes have been detected in non-small cell lung carcinomas (NSCLC), but not in inflammatory breast cancer.

Case presentation: Herein, we report a CD74-ROS1 fusion gene identified in a 64-year-old Chinese woman with inflammatory breast cancer (IBC). The patient initially presented with a rapidly growing mass in the left breast with diffuse erythema developing over a period of 2 months. Diagnosis of invasive breast carcinoma was made by core needle biopsy. Positron emission tomography-computed tomography (PET/CT) demonstrated multiple organ metastases. Genomic DNA was extracted from tumor tissue and analyzed using next-generation sequencing (NGS). The CD74-ROS1 fusion gene was detected in the genomic DNA. The patient refused crizotinib treatment, and could not tolerate the side effects of palliative chemotherapy. Unfortunately, the patient died 4 months after diagnosis.

Conclusion: We report the case of a CD74-ROS1 fusion gene in a patient with IBC. This may reveal, for the first time, a possible association between CD74-ROS1 gene fusion and rapid progression of inflammatory breast cancer. Multigene panel testing can be performed when rapidly progressive breast cancer occurs and could reveal potential therapeutic strategies.
\end{abstract}

Keywords: Inflammatory breast neoplasms, Gene fusion, Case report

\section{Background}

Inflammatory breast cancer (IBC) is a rare and aggressive disease that accounts for $\sim 2.5 \%$ of all invasive breast cancer and is characterized by rapid progression and worse prognosis [1]. The overall survival of IBC patients is shorter than that of non-IBC patients; several studies show 5-year and 15-year overall survival of approximately $40 \%$ and $20 \%$, respectively [1-3]. The identification of oncogenic drivers and subsequent targeting of these proteins could be a promising treatment strategy for IBC. Next-generation sequencing (NGS) technology provides a highly efficient method to obtain vast genomic

\footnotetext{
*Correspondence: tlli77@medmail.com.cn; zhixiao@csu.edu.cn ${ }^{1}$ Department of General Surgery, Xiangya Hospital, Central South University, Xiangya Road 87\#, Changsha, Hunan, People's Republic of China

Full list of author information is available at the end of the article
}

information which could be useful for treatment selection. In this study, we report a CD74-ROS1 fusion gene detected by NGS in a patient with IBC. Based on a literature search, chromosomal rearrangements involving the ROS1 gene were first described in non-small cell lung carcinoma (NSCLC), and CD74-ROS1 fusion transcripts were also detected in NSCLC [3, 4]. A CD74-ROS1 fusion gene in breast cancer has never been reported in the literature.

\section{Case presentation}

A 64-year-old Chinese woman presented to the clinic with a painless mass on the left breast. The mass had been present for approximately 1 year, with relatively slow progression, and had only rapidly increased in size in the past 2 months. She had no remarkable family history. A physical examination revealed diffuse erythema, skin ridging and peau d'orange appearance of the skin original author(s) and the source, provide a link to the Creative Commons licence, and indicate if changes were made. The images or other third party material in this article are included in the article's Creative Commons licence, unless indicated otherwise in a credit line to the material. If material is not included in the article's Creative Commons licence and your intended use is not permitted by statutory regulation or exceeds the permitted use, you will need to obtain permission directly from the copyright holder. To view a copy of this licence, visit http://creativecommons.org/licenses/by/4.0/. The Creative Commons Public Domain Dedication waiver (http://creativeco mmons.org/publicdomain/zero/1.0/) applies to the data made available in this article, unless otherwise stated in a credit line to the data. 
(Fig. 1). Breast mass size was $7.0 \mathrm{~cm} \times 6.5 \mathrm{~cm}$. There were multiple enlarged and fused lymph nodes in the axilla and supraclavicular region. Ultrasound showed a hypoechoic area with irregular shape and unclear border (Fig. 1). Internally, the hypoechoic area was asymmetrical, and a strong increase in blood flow was detected within the lesion. Ultrasound also showed enlarged lymph nodes in the axilla and supraclavicular region. Dynamic contrastenhanced magnetic resonance imaging (MRI) showed a heterogeneously distributed lesion of high signal intensity in the left breast on T1-weighted images. The breast mass was rapidly enhanced following the injection of gadolinium diethylenetriamine-pentaacetic acid (Fig. 2). Positron emission tomography-computed tomography
(PET/CT) indicated increased ${ }^{18} \mathrm{~F}$-fluorodeoxyglucose uptake in the left breast, in the nodes of the chest wall and the nodes of the left posterior basal lung. PET/ $\mathrm{CT}$ also demonstrated additional uptake in the internal mammary, mediastinum (4R, 4L, 5 and 7 groups) and hilum of the lung (10 and 11 groups), and bilateral cervical, retroperitoneal and bilateral iliac blood vessel lymph nodes. Increased uptake in the liver was observed as well (Fig. 3). Core needle aspiration was performed for the diagnosis of invasive ductal carcinoma of the left breast in July 2017. Diagnosis of breast carcinoma was made by both hematoxylin and eosin (HE) staining and immunostaining. This breast carcinoma was immunohistochemically negative for estrogen receptor (ER),
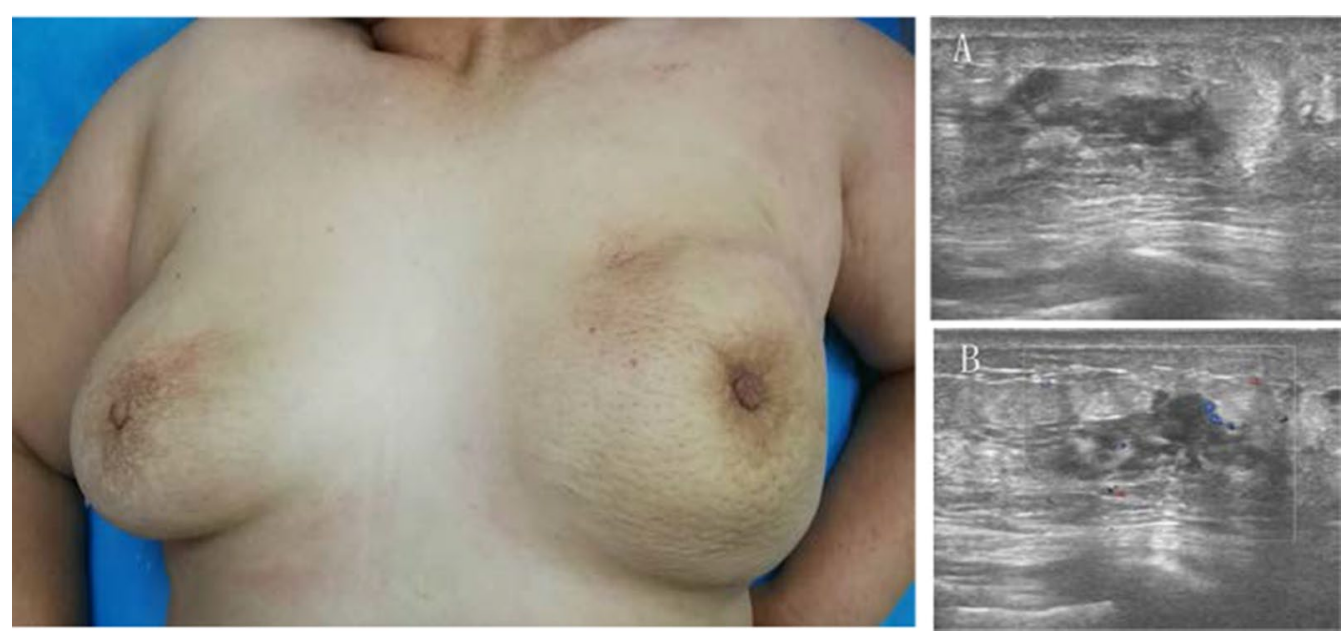

Fig. 1. Gross finding and ultrasound (US) examination. Diffuse erythema, skin ridging and peau d'orange appearance of the left breast skin. a US showed a hypoechoic area with irregular shape and unclear border. b Color Doppler US showed increased blood flow within the lesion.
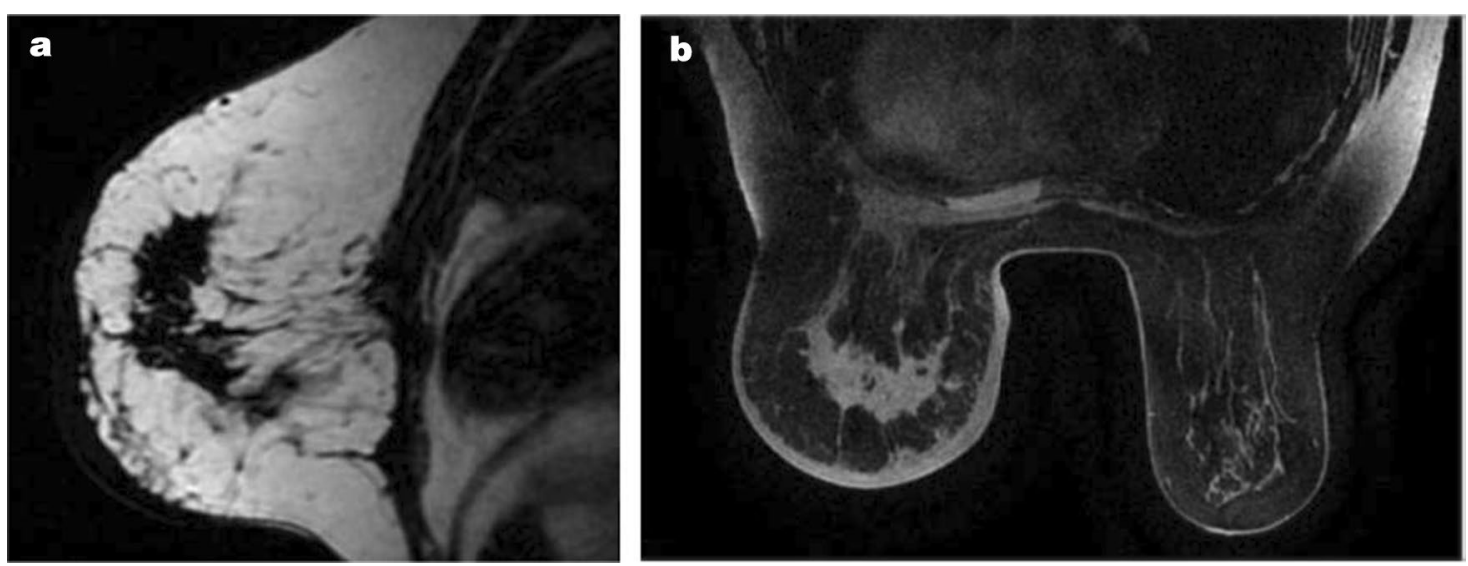

Fig. 2. Magnetic resonance imaging (MRI). MRI showed the heterogeneously distributed lesion in an area of high signal intensity in the left breast on T1-weighted images. The breast mass was rapidly enhanced following the injection of gadolinium diethylenetriamine-pentaacetic acid at an early phase (2 minutes after agent injection). 


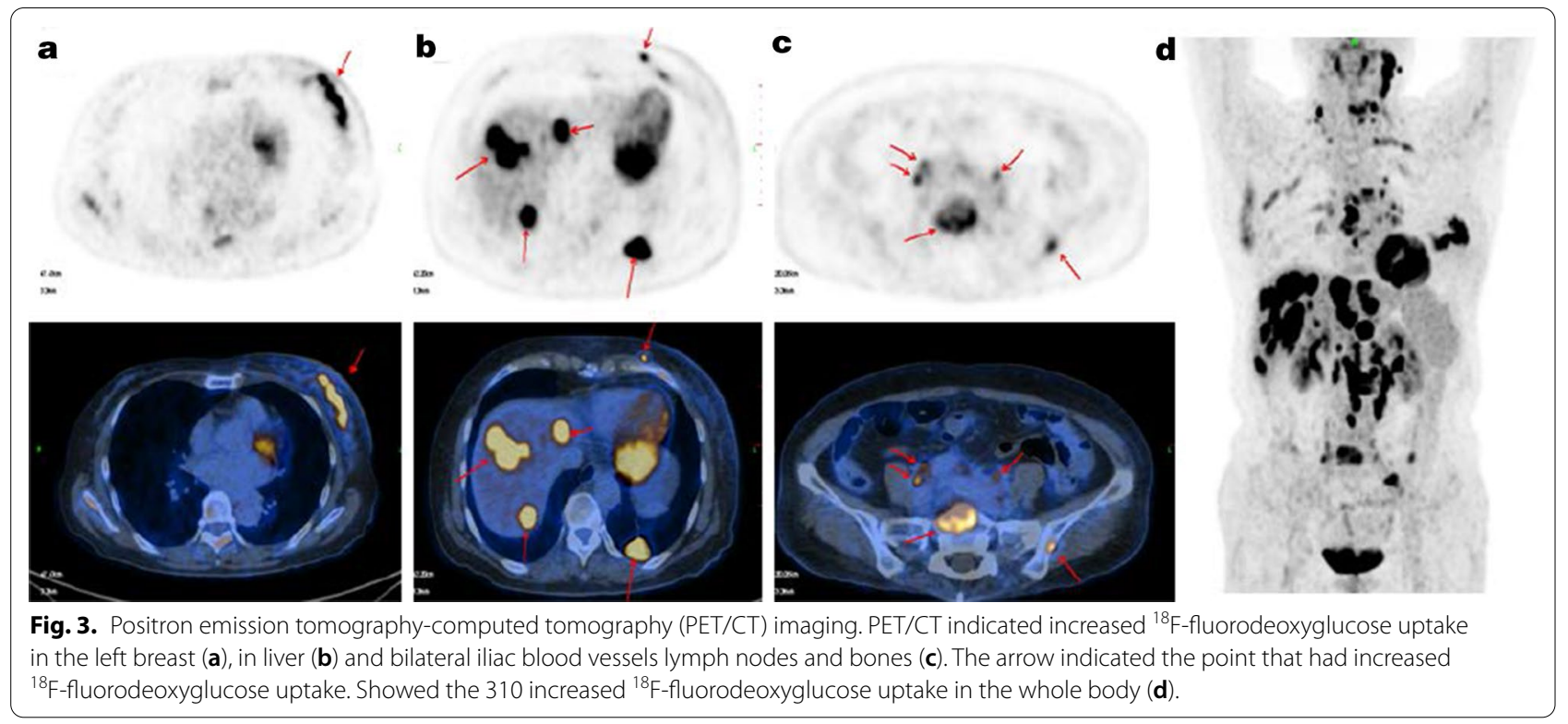

progesterone receptor (PR) and human epidermal growth factor receptor 2 (HER2). The carcinoma was immunohistochemically positive for P53, E-cadherin and epidermal growth factor receptor (EGFR) (Fig. 4). Based on these pathological results, combined with the clinical characteristics, this patient was diagnosed with IBC
(cT4N3M1). The patient was enrolled in a clinical study analyzing IBC genomic mutation status using NGS. Following verbal and written informed consent, genomic DNA was extracted from tumor tissue. Tumor tissue DNA was sequenced by target region capture sequencing using a previously described NGS technique [5].

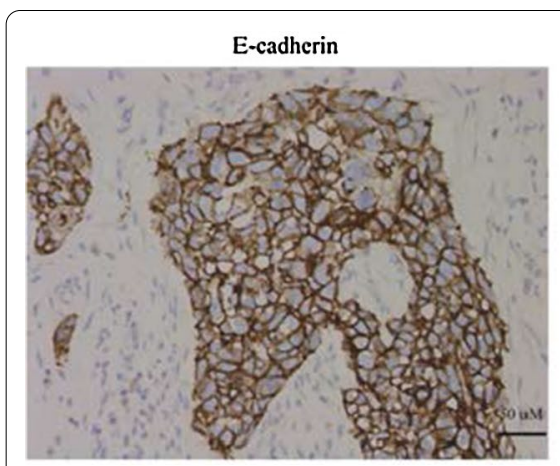

ER

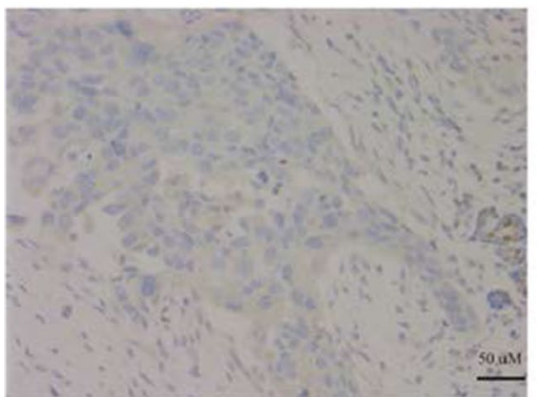

EGFR

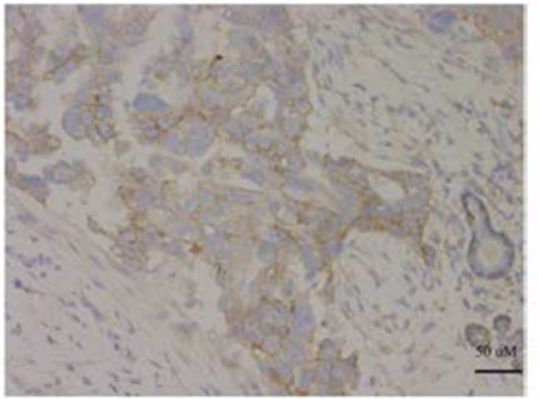

PR

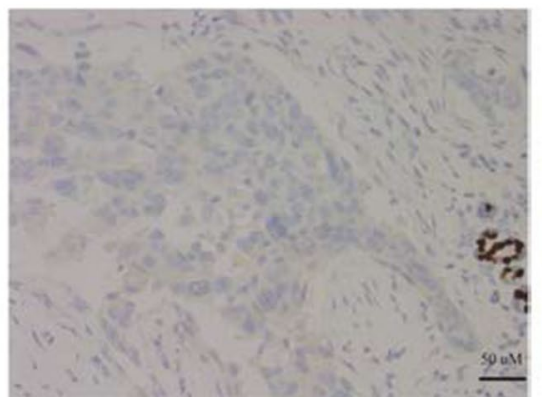

P53

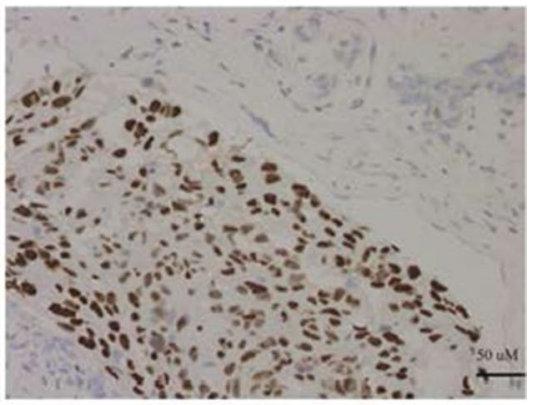

HER2

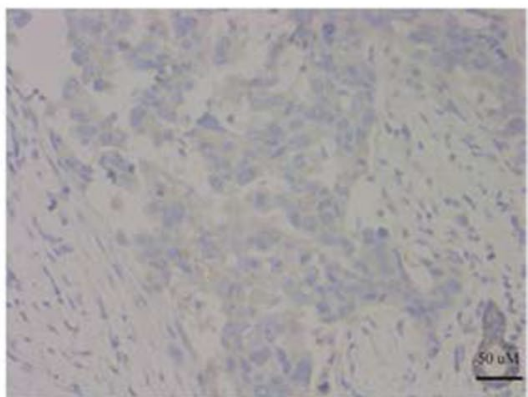

Fig. 4. Immunohistochemical staining imaging. The breast carcinoma was immunohistochemically positive for E-cadherin, epidermal growth factor receptor (EGFR) and P53, and negative for estrogen receptor, progesterone receptor and HER2. 
TP53BP1 and ARID1A nonsense mutations and a CD74ROS1 fusion gene were detected in the genomic DNA. The CD74-ROS1 fusion gene combined an exon 7 of CD74 and an exon 34 of ROS1, and the ROS1 protein was overexpressed, driven by this fusion oncogene in breast tumor tissues (Fig. 5).

Chemotherapy (paclitaxel, 120mg) was given every week for a period of 3 weeks. Oral administration of capecitabine tablets (1.5 g twice daily, days $1-14$ of a 21-day cycle) was given for three cycles due to unacceptable anorexia with paclitaxel. The patient refused crizotinib treatment for economic reasons and was confirmed dead in November 2017.

\section{Discussion and conclusion}

A CD74-ROS1 fusion gene, which has yet to be reported in a breast cancer patient, was detected in a 64-year-old Chinese woman diagnosed with IBC. This patient did not have any family history of cancer. The detected gene fusion occurred between exon 7 of CD74 and exon 34 of ROS1. ROS1 proteins were overexpressed in tumor tissue. The ROS1 gene, located on chromosome 6q22.1, encodes a receptor tyrosine kinase (RTK), and is related to cell differentiation located in specific organs. In a mouse model, transient ROS1 expression during development in the kidney, intestine and lung coincided with major morphogenetic and differentiation events in these organs [6]. Furthermore, ROS1 transcripts were directly involved in inductive interactions between epithelial and mesenchymal cells in kidney and intestine development $[6,7]$. In mice, ROS1 deficiency induced inappropriate regionalization and terminal differentiation of epithelial cells in the epididymis, whereas female ROS1-deficient mice developed normally with no affects on fertility [8]. Human ligand of ROS1 has not yet been identified, and the function of ROS1 needs further investigation [9].

A literature review revealed only one abstract reporting the occurrence of ROS1 fusion in breast cancer [10], and showed the alteration of GOPC-ROS1 fusion and response to crizotinib. In this study, we reported a novel ROS1 fusion in breast cancer. CD74-ROS1 fusion transcripts have been detected in $0.7-1.9 \%$ of patients with NSCLC [11-14]. In studies of NSCLC patients, reverse transcription polymerase chain reaction (PT-PCR), fluorescence in situ hybridization (FISH), immunohistochemistry (IHC) and NGS were the most commonly used methods to confirm the fusion gene. However, there are no approved companion assays for the diagnosis of CD74-ROS1 fusion. In this study, NGS and IHC were used for the analysis of the CD74-ROS1 fusion gene in the patient with IBC. We confirmed the CD74-ROS1 fusion gene for the first time in an IBC patient by NGS. In the IHC analysis, overexpression of the ROS1 protein in breast tumor tissue was confirmed. This is in line with results from other studies which showed overexpression of the ROS1 protein in primary lung tumor tissue and

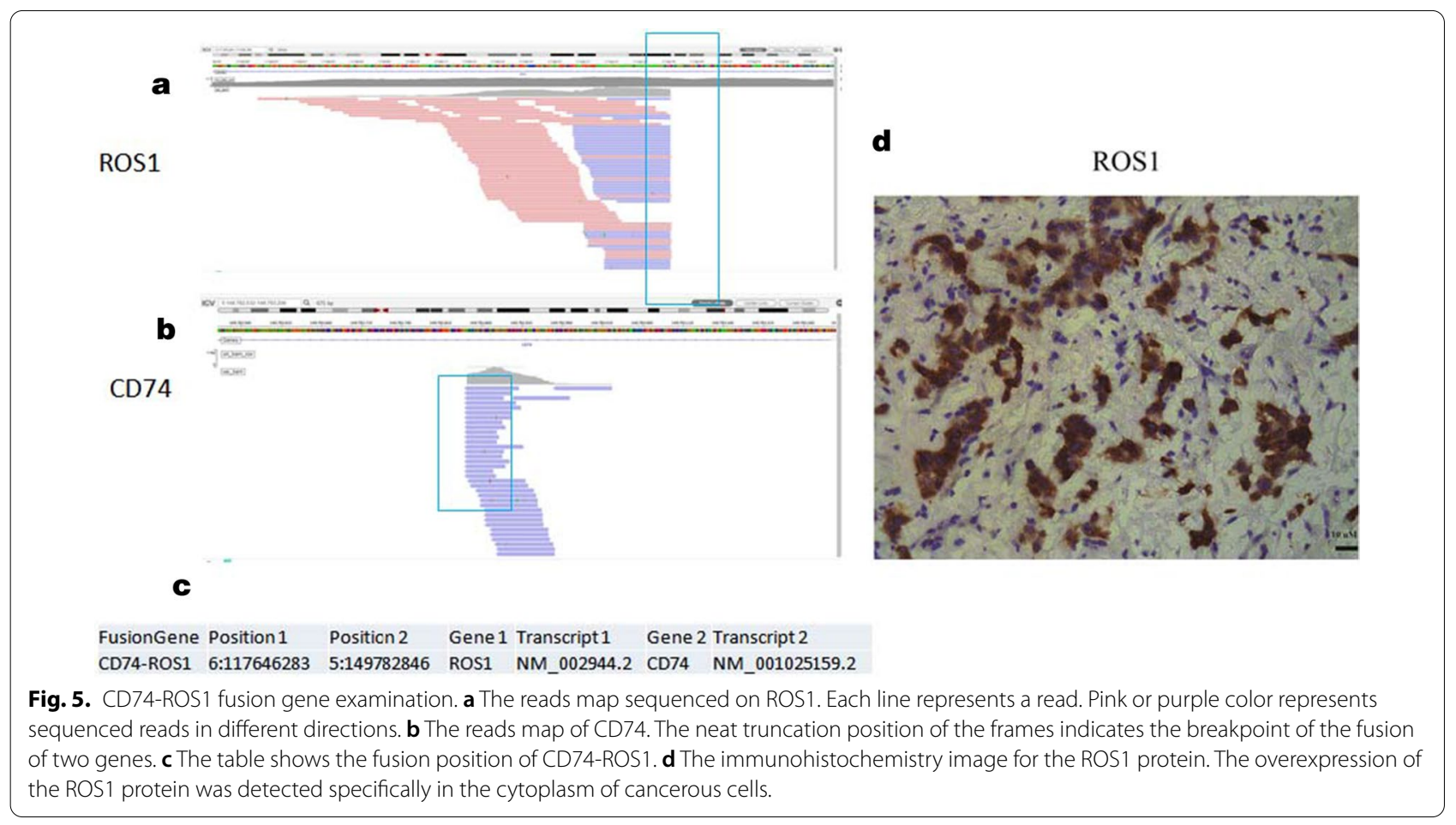


lymph node metastases when the CD74-ROS1 fusion gene was present in these tissues [3]. Crizotinib, a smallmolecule inhibitor against anaplastic lymphoma kinase (ALK) and ROS1 kinase, showed an objective response rate of $72 \%$ in a patient with NSCLC and ROS1 fusion [15]. For our patient harboring the CD74-ROS1 fusion gene, ROS1 fusion might be a viable drug target. Unfortunately, this IBC patient refused to undergo crizotinib treatment for financial reasons.

Other than the fusion gene, high mutation frequency of TP53BP1 and ARID1A was detected in this IBC patient. The TP53BP1 and ARID1A nonsense mutation frequency was $21 \%$ and $19.9 \%$, respectively. As tumor suppressor genes, TP53BP1 and ARID1A have different roles in gene repair and stability. 53BP1 functions in two major double-strand break repair pathways, promoting nonhomologous end-joining (NHEJ) and inhibiting homologydirected repair (HDR), and integrates cellular input to ensure their timely execution in the proper cellular contexts [16]. ARID1A plays a role in targeting SWI/SNF complexes to tissue-specific enhancers and in maintaining their chromatin accessibility, controlling the cell cycle and DNA damage checkpoint, and regulating P53 and telomerase activation [17]. The CD74-ROS1 fusion gene, in conjunction with the TP53BP1 and ARID1A nonsense mutations, may have contributed to the rapid progression of IBC disease in this patient, with only 18 months from discovery of breast lump to death.

In conclusion, this is the first report of a CD74-ROS1 fusion gene in a patient with IBC. Although the effect of crizotinib in patients with IBC harboring the CD74ROS1 fusion gene remains unclear, genetic sequencing may help us in designing individualized treatment.

\section{Acknowledgements}

Thanks to Geneplus Co., Ltd., for the technical support.

\section{Authors' contributions}

$\mathrm{HH}, \mathrm{JY}$ and SW collected and analyzed and interpreted the patient data. ND performed the histological examination of the breast. $\mathrm{HZ}$ collected and analyzed the pathology data. LT and ZX were major contributors in writing the manuscript. All authors read and approved the final manuscript.

\section{Funding}

Hunan Natural Science Foundation (2020JJ4916), Foundation of Clinical Research Center For Breast Cancer Control and Prevention in Hunan Province (2010-66).

\section{Availability of data and materials}

The datasets used and/or analyzed during the current study are available from the corresponding author on reasonable request.

\section{Declarations}

Ethics approval and consent to participate Ethics approval was obtained from the Xiangya Hospital ethics committee (reference number 201609606).

\section{Consent for publication}

Written informed consent was obtained from the patient for publication of this case report and any accompanying images. A copy of the written consent is available for review by the Editor-in-Chief of this journal.

\section{Competing interests}

The authors declare that they have no competing interests.

\section{Author details}

${ }^{1}$ Department of General Surgery, Xiangya Hospital, Central South University, Xiangya Road 87\#, Changsha, Hunan, People's Republic of China. ${ }^{2}$ Clinical. Research Center for Breast Cancer Control and Prevention in Hunan Province, Changsha, China. ${ }^{3}$ Department of clinical laboratory, The First Hospital of Changsha, Changsha, China. ${ }^{4}$ Department of Pathology, Xiangya Hospital, Central South University, Changsha, China.

Received: 11 September 2020 Accepted: 20 April 2021

Published online: 30 May 2021

\section{Reference}

1. Matro JM, Li T, Cristofanilli M, Hughes ME, Ottesen RA, Weeks JC, Wong YN. Inflammatory breast cancer management in the national comprehensive cancer network: the disease, recurrence pattern, and outcome. Clin Breast Cancer. 2015;15:1-7.

2. Takeuchi K, Soda M, Togashi Y, Suzuki R, Sakata S, Hatano S, Asaka R, Hamanaka W, Ninomiya $\mathrm{H}$, Uehara $\mathrm{H}$, et al. RET, ROS1 and ALK fusions in lung cancer. Nat Med. 2012;18:378-81.

3. Matsuura S, Shinmura K, Kamo T, Igarashi H, Maruyama K, Tajima M, Ogawa H, Tanahashi M, Niwa H, Funai K, et al. CD74-ROS1 fusion transcripts in resected non-small cell lung carcinoma. Oncol Rep. 2013:30:1675-80

4. Roskoski R Jr. ROS1 protein-tyrosine kinase inhibitors in the treatment of ROS1 fusion protein-driven non-small cell lung cancers. Pharmacol Res. 2017;121:202-12.

5. Liu J, Li J, Wang H, Wang Y, He Q, Xia X, Hu ZY, Ouyang Q. Clinical and genetic risk factors for Fulvestrant treatment in post-menopause ERpositive advanced breast cancer patients. J Transl Med. 2019;17:27.

6. Sonnenberg E, Godecke A, Walter B, Bladt F, Birchmeier C. Transient and locally restricted expression of the ros 1 protooncogene during mouse development. EMBO J. 1991;10:3693-702.

7. Tessarollo L, Nagarajan L, Parada LF. c-ros: the vertebrate homolog of the sevenless tyrosine kinase receptor is tightly regulated during organogenesis in mouse embryonic development. Development. 1992:115:11-20.

8. Sonnenberg-Riethmacher E, Walter B, Riethmacher D, Godecke S, Birchmeier C. The c-ros tyrosine kinase receptor controls regionalization and differentiation of epithelial cells in the epididymis. Genes Dev. 1996;10:1184-93.

9. Lin JJ, Shaw AT. Recent advances in targeting ROS1 in lung cancer. J Thorac Oncol. 2017;12:1611-25.

10. Liao L, Song M, Li X, Tang L, Zhang T, Zhang L, Pan Y, Chouchane L, Ma $X$. E3 ubiquitin ligase UBR5 drives the growth and metastasis of triplenegative breast cancer. Cancer Res. 2017;77:2090-101.

11. Bergethon K, Shaw AT, Ou SH, Katayama R, Lovly CM, McDonald NT, Massion PP, Siwak-Tapp C, Gonzalez A, Fang R, et al. ROS1 rearrangements define a unique molecular class of lung cancers. J Clin Oncol. 2012;30:863-70.

12. Rimkunas VM, Crosby KE, Li D, Hu Y, Kelly ME, Gu TL, Mack JS, Silver MR, Zhou X, Haack H. Analysis of receptor tyrosine kinase ROS1-positive tumors in non-small cell lung cancer: identification of a FIG-ROS1 fusion. Clin Cancer Res. 2012;18:4449-57.

13. Davies KD, Le AT, Theodoro MF, Skokan MC, Aisner DL, Berge EM, Terracciano LM, Cappuzzo F, Incarbone $M$, Roncalli $M$, et al. Identifying and targeting ROS1 gene fusions in non-small cell lung cancer. Clin Cancer Res. 2012;18:4570-9.

14. Yoshida A, Kohno T, Tsuta K, Wakai $\mathrm{S}$, Arai Y, Shimada Y, Asamura H, Furuta K, Shibata T, Tsuda H. ROS1-rearranged lung cancer: a clinicopathologic and molecular study of 15 surgical cases. Am J Surg Pathol. 2013;37:554-62 
15. Shaw AT, Ou SH, Bang YJ, Camidge DR, Solomon BJ, Salgia R, Riely GJ, Varella-Garcia M, Shapiro Gl, Costa DB, et al. Crizotinib in ROS1-rearranged non-small-cell lung cancer. N Engl J Med. 2014;371:1963-71.

16. Zimmermann M, de Lange T. 53BP1: pro choice in DNA repair. Trends Cell Biol. 2014;24:108-17.

17. Mathur R. ARID1A loss in cancer: towards a mechanistic understanding. Pharmacol Ther. 2018;190:15-23.

\section{Publisher's Note}

Springer Nature remains neutral with regard to jurisdictional claims in published maps and institutional affiliations.
Ready to submit your research? Choose BMC and benefit from:

- fast, convenient online submission

- thorough peer review by experienced researchers in your field

- rapid publication on acceptance

- support for research data, including large and complex data types

- gold Open Access which fosters wider collaboration and increased citations

- maximum visibility for your research: over $100 \mathrm{M}$ website views per year

At BMC, research is always in progress.

Learn more biomedcentral.com/submissions 